\title{
ANALISIS QUALITY OF SERVICE JARINGAN WIRELESS SUKANET WIFi DI FAKULTAS SAINS DAN TEKNOLOGI UIN SUNAN KALIJAGA
}

\author{
Bambang Sugiantoro $^{1}$, Yuha Bani Mahardhika ${ }^{2}$ \\ Teknik Informatika UIN Sunan Kalijaga Yogyakarta \\ E-mail: bambang.sugiantoro@uin-suka.ac.id, yuhabm@gmail.com
}

\begin{abstract}
ABSTRAK
Performa layanan jaringan Internet pada UIN Sunan Kalijaga Fakultas Sains dan Teknologi masih belum maksimal, yaitu memiliki tingkat kualitas delay sebesar 159 milidetik menurut TIPHON Bagus. Besar Throughput sebesar 9.0 MBps dan presentase Throughput sebesar $50 \%$ dikategorikan menurut standarisasi TIPHON sedang. Dan memiliki nilai packet loss ratio sebesar $36 \%$ dikategorikan menurut standarisasi TIPHON adalah jelek.
\end{abstract}

Kata Kunci: Analisis, QoS, delay, packet loss, throughput

\begin{abstract}
Internet service network performance in Islamic State University of Sunan Kalijaga environment in the faculty of science and technology area is still not maximal. It has a delay quality level of 159 milliseconds according to good TIPHON. Large throughput of $9.0 \mathrm{Mbps}$ and throughput percentage of $50 \%$ are categorized according to standardized of normal TIPHON and it has a value of packet loss ratio of $36 \%$ categorized according to TIPHON standardization is bad.
\end{abstract}

Keywords: Analysis, QoS, delay, packet loss, throughput

DOI: $10.15408 /$ jti.v10i2.7027 


\section{PENDAHULUAN}

Jaringan internet pada saat ini telah menjadi salah satu hal yang paling di butuhkan pada era teknologi informasi seperti saat ini. Tidak bisa dibayangkan jika pada era teknologi informasi seperti saat ini tanpa menggunakan teknologi jaringan internet. Namun di era sekarang internet bukanlah hal yang sulit. Kehadiran internet di lingkungan perusahaan, kampus, sekolah, maupun instansi lain sudah sangat di butuhkan mengingat bahwa teknologi informasi ini telah memberikan kemudahan dalam mendukung proses komunikasi dan sarana prasarana yang akan dilakukan. Hal ini dapat dilihat dari penggunaan jaringan internet baik itu secara umum maupun pribadi, banyaknya kebutuhan akan akses dan komunikasi maka kinerja jaringan harus berada pada kondisi yang baik. Jaringan internet itu sendiri adalah sebuah jaringan yang terhubung antar komputer satu dengan yang lain dan dapat saling bertukar informasi melalui perangkat keras seperti modem, router, dan sebagainya. Maka pihak penyedia layanan jaringan internet harus dapat memecahkan masalah utama yaitu menyediakan kinerja layanan yang bagus untuk dapat memberikan layanan yang nyaman kepada pengguna.

Dengan adanya kualitas internet yang bagus maka hal ini dapat membantu dan menunjang sarana pra-sarana dalam mengolah data dan bertukar informasi. Salah satunya yaitu UIN Sunan Kalijaga adalah salah satu universitas negeri di Yogyakarta yang menggunakan layanan jaringan internet untuk menunjang berlangsungnya proses kegiatan akademik. Karena pada saat ini jaringan internet sangat diperlukan oleh mahasiswa, dosen, ataupun staff di UIN Sunan Kalijaga. Di UIN Sunan Kalijaga sendiri menggunakan layanan jaringan Nirkabel (Wireless) untuk menunjang sarana dan pra-sarana Akademik. Perlu di ketahui layanan berbasis Nirkabel (wireless) merupakan jaringan dengan medium berupa gelombang elektromagnetik. Pada jaringan ini tidak diperlukan kabel untuk menghubungkan antar komputer karena menggunakan gelombang elektromagnetik yang akan mengirimkan sinyal informasi antar komputer jaringan.

\section{LANDASAN TEORI}

\subsection{Wireless LAN}

Jaringan nirkabel ini merupakan salah satu media transmisi yang menggunakan gelombang radio sebagai media transmisinya. Data-data digital yang dikirim melalui wireless akan dimodulasikan ke dalam gelombang elektromagnetik. Media wireless yang umum digunakan adalah dengan menggunakan gelombang radio yang diset untuk bekerja di bidang frekuensi tertentu sesuai dengan standar.

\subsection{Jaringan komputer}

Sebuah sistem jaringan yang terdiri dari komputer dan perangkat-perangkat jaringan yang saling berhubungan bertukar informasi dan juga saling bekerjasama. Jaringan komputer juga merupakan sebuah himpunan "interkoneksi" antara 2 komputer atau lebih yang saling terhubung oleh media transmisi kabel atau nirkabel [2].

\subsection{QoS}

Menurut [3] (Dalam jurnal Qos) kualitas layanan/Qos (Quality of Service) adalah kemampuan sebuah jaringan untuk menyediakan layanan yang lebih baik lagi bagi layanan trafik yang melewatinya. QoS merupakan sebuah sistem arsitektur end to end dan bukan merupakan sebuah feature yang dimiliki oleh jaringan. Quality of Service suatu network merujuk ke tingkat kecepatan dan keandalan penyampaian berbagai jenis beban data di dalam suatu komunikasi.

\subsection{Delay}

Menurut [4] Delay adalah waktu tunda suatu paket yang diakibatkan oleh proses transmisi dari satu titik ke titik lain yang menjadi tujuannya.

\subsection{Packet Loss}

Menurut [4] Packet loss didefinisikan sebagai kegagalan transmisi paket IP mencapai tujuannya.

\subsection{Throughput}

Jumlah total kedatangan paket IP sukses yang diamati di tempat pengukuran pada destination selama interval waktu tertentu dibagi oleh durasi interval waktu tersebut (Sama dengan, jumlah pengiriman paket IP sukses per service-second). Throughput lebih pada menggambarkan bandwidth yang 
sebenarnya pada waktu tertentu dan pada kondisi dan jaringan internet tertentu yang digunakan untuk men-download suatu file dengan ukuran tertentu.

\section{HASIL DAN PEMBAHASAN}

\subsection{Analisis kebutuhan}

Dengan melakukan wawancara dengan salah satu pengurus PTIPD UIN Sunan Kalijaga Yogyakarta, didapat hasil bahwa jaringan SUKAnet dibagi menjadi 3 jalur pembagian bandwidth yaitu jalur 11.200, 11.201, dan 11.202. Pada penelitian ini mengambil studi kasus di Fakultas Sains dan Teknologi. Jaringan Fakultas Sains dan Teknologi berada pada jalur 11.202, dan berdasarkan data mapping access point yang telah diperoleh terdapat 9 access point yang bertujuan untuk memenuhi kebutuhan akses internet mahasiswa, staff, dan dosen. Agar pembagian bandwidth dapat merata. Dari wawancara tersebut kemudian didapat hasil capture trafik pengguna SUKAnet Wifi yang akan digunakan sebagai landasan penulis dalam melakukan pengujian parameter QoS. Untuk gambar capture trafik pengguna SUKAnet wifi dapat dilihat pada gambar dibawah ini.

\begin{tabular}{|c|c|c|c|c|c|c|c|c|c|}
\hline Cllent MAC Addr & AP Name & WLAN Proffle & WLAN SSID & Protocol & Status & Auth & Port & WGB & \\
\hline 00:07:a8:5b:81:22 & AP2894.0f58.dd8e & 300-SUKAnet-wif & SUKAnet wiff & $802.11 \mathrm{bn}$ & Assoclated & Yes & 1 & No & 믐 \\
\hline 00:07:a8:5e:b5:82 & AP2894.0f58.debe & 300-SUKAnet-win & SUKAnet wif & $802.11 \mathrm{bn}$ & Assoclated & Yes & 1 & No & D \\
\hline 00:07:a8:70:Zaide & AP2894.0f58.de60 & 300-SUKAnet-wif & SUKAnet wif & $802.11 \mathrm{bn}$ & Assoclated & Yes & 1 & No & D \\
\hline Q0:07:a8:Z11:at:66 & AP2894.0058.dd8d & 300-SUKAnet-wif & SUKAnet wif & $802.11 \mathrm{bn}$ & Assoclated & Yes & 1 & No & D \\
\hline 00:08:22:08:ea:6b & AP2894.0663.0664 & 300-SUKAnet-wif & SUKAnet wif & $802.11 \mathrm{bn}$ & Assoclated & Yes & 1 & No & E \\
\hline $00: 08: 22: 26: 26: 13$ & AP2894.0039.39b2 & 300-SUKAnet-wif & SUKAnet wif & $802.11 \mathrm{bn}$ & Associated & Yes & 1 & No & D \\
\hline 20:08:22:43:4e:54 & AP2894.0058.deca & 300-SUKAnet-wif & SUKAnet wif & $802.11 \mathrm{bn}$ & Assoclated & Yes & 1 & No & D \\
\hline 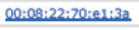 & AP2894.0f58.dd8d & 300-SUKAnet-wif & SUKAnet wif & $802.11 \mathrm{bn}$ & Associated & Yes & 1 & No & E \\
\hline 00:08:22:3cidz:fit & AP2894.0f58.dd8d & 300-SUKAnet-wif & SUKAnet wif & $802.11 \mathrm{bn}$ & Assoclated & Yes & 1 & No & D \\
\hline 00:08:22:ce:5a:49 & AP2894.0663.0664 & 300-SUKAnet-wif & SUKAnet wif & $802.11 \mathrm{bn}$ & Associated & Yes & 1 & No & D \\
\hline 00:08:22:e0:1dic4 & AP2894.0f58.dafc & 300-SUKAnet-wif & suKanet wif & $802.11 \mathrm{bn}$ & Assoclated & Yes & 1 & No & E \\
\hline $00: 08: 22: f 8: 83: 15$ & AP2899.0f58.dc2f & 300-SUKAnet-wif & SUKAnet wif & $802.11 \mathrm{bn}$ & Associated & Yes & 1 & No & D \\
\hline $00: 09: 00: 55: c 1: 89$ & AP2894.0+39.39b2 & 300-SUKAnet-wif & SUKAnet wif & $802.11 \mathrm{bn}$ & Assoclated & Yes & 1 & No & D \\
\hline Q0:0a:00:58:b9:48 & AP2894.0f58.dd8e & 300-SUKAnet-wif & SUKAnet wif & $802.11 \mathrm{bn}$ & Assoclated & Yes & 1 & No & D \\
\hline 0:0:aa:00:60:2t:80 & AP2894.0663.d802 & 300-SUKAnet-wif & SUKAnet wif & $802.11 \mathrm{bn}$ & Assoclated & Yes & 1 & No & - \\
\hline $00: 09: 00: 68: 58: 63$ & AP2894.0fa9.d202 & 300-SUKAnet-wif & SUKAnet wif & $802.11 \mathrm{bn}$ & Assoclated & Yes & 1 & No & - \\
\hline Q0:0a:00:a2:3atib3 & AP2894.0663.d7d0 & 300-SUKAnet-wif & SUKAnet wif & $802.11 \mathrm{bn}$ & Assoclated & Yes & 1 & No & D \\
\hline Q0i:0a:00ibtiaziced & AP2894.0fa9.d202 & 300-SUKAnet-wif & SUKAnet wif & $802.11 \mathrm{bn}$ & Assoclated & Yes & 1 & No & D \\
\hline Q0:0a:00:d0:5e:81 & AP2894.0f58.deca & 300-SUKAnet-wif & SUKAnet wif & $802.11 \mathrm{bn}$ & Assoclated & Yes & 1 & No & - \\
\hline QQ:ea:el:dcatf6:9d & AP2894.0f58.dfdc & 300-SUKAnet-wif & SUKAnet wif & $802.11 \mathrm{bn}$ & Assoclated & Yes & 1 & No & $\boldsymbol{\nabla}$ \\
\hline Q0:0a:00:ddilcci5e & AP2894.0t58.ddc3 & 300-SUKAnet-wif & SUKAnet wif & $802.11 \mathrm{bn}$ & Assoclated & Yes & 1 & No & D \\
\hline Q0:0a:00:deiadi30 & AP2894.0f58.dec5 & 300-SUKAnet-wif & SUKAnet wif & $802.11 \mathrm{bn}$ & Assoclated & Yes & 1 & No & - \\
\hline 00:0a:5:0a:60:50 & AP2894.0058.dddo & 300-suKAnet-wif & SUKAnet wif & $802.11 \mathrm{bn}$ & Assoclated & Yes & 1 & No & $\mathbf{D}$ \\
\hline $00: 0 a+45: 43 ; c 8: 18$ & AP2894.0f58.ddf4 & 300-SUKAnet-wif & SUKAnet wif & $802.11 \mathrm{bn}$ & Assoclated & Yes & 1 & No & D \\
\hline 00:0a:f5:4t:ber:c4 & AP2894.0f58.dc2f & 300-SUKAnet-wif & SUKAnet wif & $802.11 \mathrm{bn}$ & Associated & Yes & 1 & No & D \\
\hline $00: 0 a+5:=3 ; 40: 38$ & AP2894.0663.d802 & 300-SUKAnet-wif & SUKAnet wif & $802.11 \mathrm{bn}$ & Assoclated & Yes & 1 & No & D \\
\hline Q0:0a:+5ietialib8 & AP2894.0663.d84f & 300-SUKAnet-wif & SUKAnet wif & $802.11 \mathrm{bn}$ & Assoclated & Yes & 1 & No & - \\
\hline 00:0с:ez:10:03:32 & AP2894.0058.dd71 & 300-suKAnet-wif & SUKAnet wif & $802.11 \mathrm{bn}$ & Assoclated & Yes & 1 & No & D \\
\hline $00: 12: 36: 52: 50: c 2$ & AP2894.0039.39b2 & 300-SUKAnet-wif & SUKAnet wif & $802.11 \mathrm{bn}$ & Assoclated & Yes & 1 & No & - \\
\hline Q0:16:d4:ee:27:9d & AP2894.0058.dct5 & 300-SUKAnet-wif & SUKAnet wif & $802.11 \mathrm{bn}$ & Assoclated & Yes & 1 & No & D \\
\hline Q0:La:as:at:2d:06 & AP2894.0663.d800 & 300-SUKAnet-wif & SUKAnet wif & $802.11 \mathrm{bn}$ & Associated & Yes & 1 & No & D \\
\hline Q0:1a:28:79:52:ch & AP2894.0039.39b2 & 300-SUKAnet-wif & SUKAnet wif & $802.11 \mathrm{bn}$ & Assoclated & Yes & 1 & No & D \\
\hline 00:1a:99:e0:9tid4 & AP2894.0f58.dddf & 300-SUKAnet-wif & SUKAnet wif & $802.11 \mathrm{bn}$ & Assoclated & Yes & 1 & No & च \\
\hline Q0:1cizbiab:a2:d3 & AP2894.0fa9.dod7 & 300-SUKAnet-win & SUKAnet wif & $802.11 \mathrm{bn}$ & Assoclated & Yes & 1 & No & - \\
\hline $00: 1 c: 7 b \cdot d 4: 80: 4 c$ & APC464.1300.35ef & 300-SUKAnet-wif & SUKAnet wif & $802.11 \mathrm{bn}$ & Assoclated & Yes & 1 & No & - \\
\hline $00: 21: 00:\{4: 83: 96$ & AP2894.0f58.dd71 & 300-SUKAnet-wif & SUKAnet wif & 802.119 & Assoclated & Yes & 1 & No & च \\
\hline $00: 22: f b: 43: 3 a: 62$ & AP2894.0058.dfc7 & 300-SUKAnet-wif & SUKAnet wif & $802.11 \mathrm{bn}$ & Assoclated & Yes & 1 & No & - \\
\hline
\end{tabular}

Gambar 1. Capture trafik pengguna SUKAnet Wifi

Kemudian hasil capture yang didapatkan diolah untuk mengetahui trafik terpadat menggunakan perintah SQL query
phpMyAdmin, berikut adalah gambar data capture trafik menggunakan phpMyAdmin. 


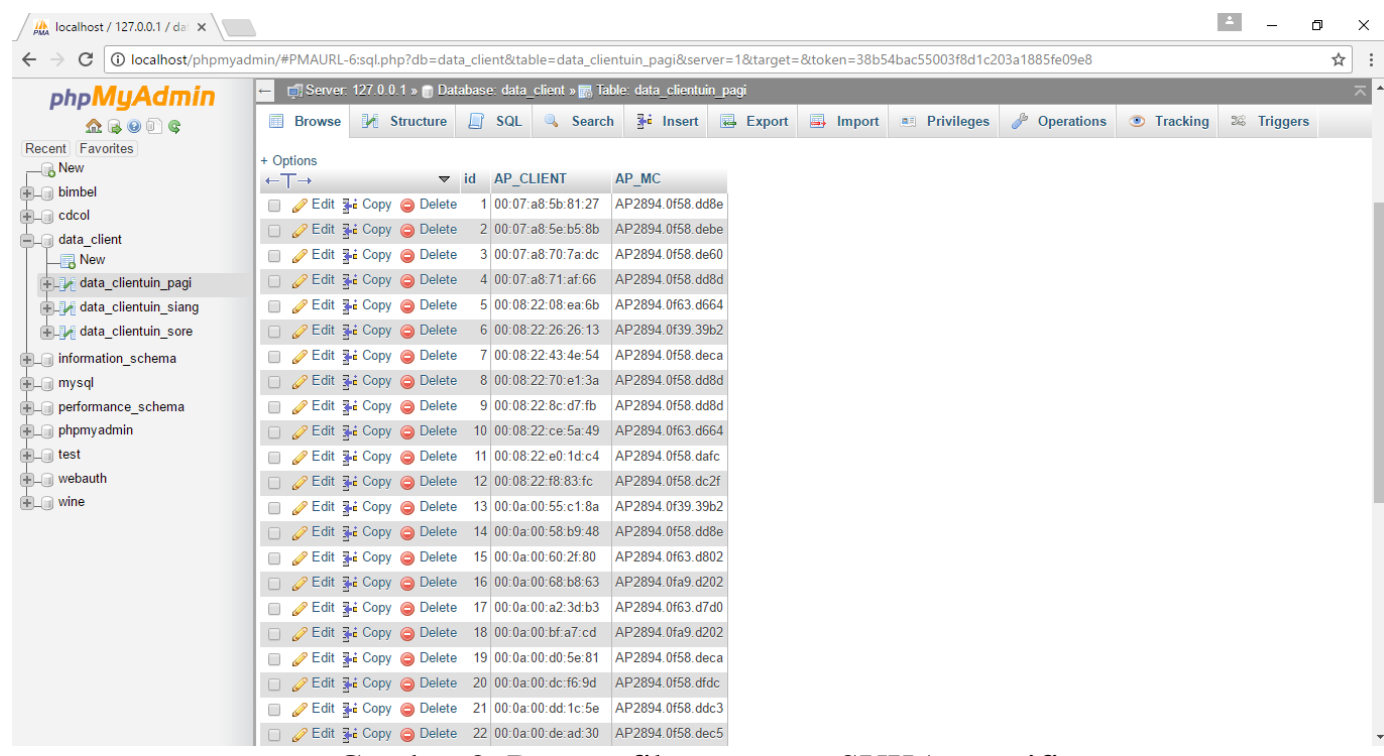

Gambar 2. Data trafik pengguna SUKAnet wifi

Adapun hasil pengujian delay yang dilakukan pada Fakultas Sains dan Teknologi UIN Sunan Kalijaga Yogyakarta, data hasil pengujian Throughput, Packet Loss, Delay Lt.1 dapat dilihat pada tabel 1, 2, dan 3:

Tabel 1. Throughput SUKAnet WiFi Lt.1

\begin{tabular}{cccc}
\hline \multirow{2}{*}{$\begin{array}{c}\text { Hari } \\
\text { Ke }\end{array}$} & $\begin{array}{c}\text { Total paket } \\
(\text { Mbytes })\end{array}$ & Perhitungan Throughput \\
\hline 1 & 7639 & 60 & Throughput (MBps) \\
2 & 6592 & 60 & 12.7 \\
3 & 5497 & 60 & 11.0 \\
4 & 6109 & 60 & 9.2 \\
5 & 5280 & 60 & 10.2 \\
6 & 5904 & 60 & 8.8 \\
& Rata-rata & & 9.8 \\
\end{tabular}

Tabel 2. Packet Loss SUKAnet WiFi Lt.1

\begin{tabular}{cccc}
\hline Hari & \multicolumn{3}{c}{ Paket } \\
\cline { 2 - 4 } Ke & $\begin{array}{c}\text { Jumlah paket } \\
\text { diterima (paket) }\end{array}$ & $\begin{array}{c}\text { Jumlah paket dikirim } \\
\text { (paket) }\end{array}$ & $\begin{array}{c}\text { Pengukuran packet loss } \\
\text { ratio }(\%)\end{array}$ \\
\hline 1 & 59 & 60 & 2 \\
2 & 14 & 60 & 77 \\
3 & 45 & 60 & 24 \\
4 & 49 & 60 & 18 \\
5 & 51 & 60 & 16 \\
6 & 40 & 60 & 33 \\
& Rata-rata & & 28 \\
\hline
\end{tabular}


Tabel 3. Delay SUKAnet WiFi Lt.1

\begin{tabular}{cccccc}
\hline \multirow{2}{*}{$\begin{array}{c}\text { Hari } \\
\text { Ke }\end{array}$} & $\begin{array}{c}\text { Waktu paket } \\
\text { diterima } \\
\text { (millisecond) }\end{array}$ & $\begin{array}{c}\text { Waktu paket } \\
\text { dikirim } \\
\text { (millisecond) }\end{array}$ & $\begin{array}{c}\text { Selisih waktu } \\
\text { (millisecond) }\end{array}$ & Paket data & $\begin{array}{c}\text { Delay } \\
\text { (millisecond) }\end{array}$ \\
\hline 1 & 3175 & 2876 & 299 & 4 & 75 \\
2 & 4418 & 3971 & 447 & 4 & 112 \\
3 & 4108 & 3711 & 397 & 4 & 99 \\
4 & 4304 & 3840 & 464 & 4 & 116 \\
5 & 3808 & 2971 & 837 & 4 & 209 \\
6 & 3528 & 2741 & 787 & 4 & 197 \\
& Rata-rata & & & & 135 \\
\hline
\end{tabular}

Adapun hasil pengujian delay yang dilakukan pada Fakultas Sains dan Teknologi pengujian Throughput, Packet Loss, Delay Lt.2 UIN Sunan Kalijaga Yogyakarta, data hasil dapat dilihat pada tabel 4, 5, dan 6:

Tabel 4. Throughput SUKAnet WiFi Lt.2

\begin{tabular}{cccc}
\hline \multirow{2}{*}{$\begin{array}{c}\text { Hari } \\
\text { Ke }\end{array}$} & \multicolumn{3}{c}{ Perhitungan Throughput } \\
\cline { 2 - 4 } & total paket (Mbytes) & Waktu pengukuran (second) & $\begin{array}{c}\text { Throughput } \\
\text { (MBps) }\end{array}$ \\
\hline 1 & 7842 & 60 & 13.1 \\
2 & 5692 & 60 & 9.5 \\
3 & 4978 & 60 & 8.3 \\
4 & 6190 & 60 & 10.3 \\
5 & 6890 & 60 & 11.5 \\
6 & 5694 & 60 & 9.5 \\
& Rata-rata & & 10.4 \\
\hline
\end{tabular}

Tabel 5. Packet Loss SUKAnet WiFi Lt.2

\begin{tabular}{cccc}
\hline Hari & \multicolumn{3}{c}{ Paket } \\
\cline { 2 - 4 } & $\begin{array}{c}\text { Jumlah paket } \\
\text { diterima (paket) }\end{array}$ & $\begin{array}{c}\text { Jumlah paket dikirim } \\
\text { (paket) }\end{array}$ & $\begin{array}{c}\text { Pengukuran packet } \\
\text { loss ratio (\%) }\end{array}$ \\
\hline 1 & 29 & 60 & 32 \\
2 & 9 & 60 & 85 \\
3 & 42 & 60 & 30 \\
4 & 59 & 60 & 2 \\
5 & 59 & 60 & 2 \\
6 & 45 & 60 & 24 \\
& Rata-rata & & 29 \\
\hline
\end{tabular}


Tabel 6. Delay SUKAnet WiFi Lt.2

\begin{tabular}{cccccc}
\hline \multirow{2}{*}{$\begin{array}{c}\text { Hari } \\
\text { Ke }\end{array}$} & $\begin{array}{c}\text { Waktu paket } \\
\text { diterima } \\
\text { (millisecond) }\end{array}$ & $\begin{array}{c}\text { Waktu paket } \\
\text { dikirim } \\
\text { (millisecond) }\end{array}$ & $\begin{array}{c}\text { Selisih } \\
\text { waktu } \\
\text { (millisecond) }\end{array}$ & $\begin{array}{c}\text { Paket } \\
\text { data }\end{array}$ & $\begin{array}{c}\text { Delay } \\
\text { (millisecond) }\end{array}$ \\
\hline 1 & 4145 & 3798 & 347 & 4 & 87 \\
2 & 4908 & 4101 & 807 & 4 & 202 \\
3 & 3775 & 2981 & 794 & 4 & 199 \\
4 & 4714 & 3982 & 732 & 4 & 183 \\
5 & 3403 & 2982 & 421 & 4 & 105 \\
6 & 3301 & 2847 & 454 & 4 & 114 \\
& Rata-rata & & & & \\
\hline
\end{tabular}

Adapun hasil pengujian delay yang dilakukan pada Fakultas Sains dan Teknologi UIN Sunan Kalijaga Yogyakaarta, data hasil

pengujian Throughput, Packet Loss, Delay Lt.3 dapat dilihat pada tabel 7, 8, dan 9:

Tabel 7. Throughput SUKAnet WiFi Lt.3

\begin{tabular}{cccc}
\hline \multirow{2}{*}{$\begin{array}{c}\text { Hari } \\
\text { Ke }\end{array}$} & $\begin{array}{c}\text { Total paket } \\
\text { (Mbytes) }\end{array}$ & Perhitungan Throughput \\
\hline 1 & 5385 & 60 & $\begin{array}{c}\text { Throughput } \\
\text { (MBps) }\end{array}$ \\
2 & 4590 & 60 & 9.0 \\
3 & 5145 & 60 & 7.7 \\
4 & 4093 & 60 & 8.6 \\
5 & 6780 & 60 & 6.8 \\
6 & 4871 & 60 & 11.3 \\
& Rata-rata & & 8.1 \\
\hline
\end{tabular}

Tabel 8. Packet Loss SUKAnet WiFi Lt.3

\begin{tabular}{cccc}
\hline \multirow{3}{*}{$\begin{array}{c}\text { Hari } \\
\text { Ke }\end{array}$} & $\begin{array}{c}\text { Jumlah paket } \\
\text { diterima (paket) }\end{array}$ & Jumlah paket dikirim (paket) & $\begin{array}{c}\text { Pengukuran } \\
\text { Packet Loss Ratio } \\
(\%)\end{array}$ \\
\hline 1 & 49 & 60 & 18 \\
2 & 42 & 60 & 30 \\
3 & 45 & 60 & 24 \\
4 & 9 & 60 & 85 \\
5 & 40 & 60 & 33 \\
6 & 45 & 60 & 24 \\
& Rata-rata & & 36 \\
\hline
\end{tabular}


Tabel 9. Delay SUKAnet WiFi Lt.3

\begin{tabular}{cccccc}
\hline \multirow{5}{*}{$\begin{array}{c}\text { Hari } \\
\text { Ke }\end{array}$} & $\begin{array}{c}\text { Waktu paket } \\
\text { diterima } \\
\text { (millisecond) }\end{array}$ & $\begin{array}{c}\text { Waktu paket } \\
\text { dikirim } \\
\text { (millisecond) }\end{array}$ & $\begin{array}{c}\text { Selisih waktu } \\
\text { (millisecond) }\end{array}$ & Paket data & $\begin{array}{c}\text { Delay } \\
\text { (millisecond) }\end{array}$ \\
\hline 1 & 4332 & 3782 & 550 & 4 & 138 \\
2 & 4739 & 3983 & 756 & 4 & 189 \\
3 & 3662 & 2994 & 668 & 4 & 167 \\
4 & 3414 & 2892 & 522 & 4 & 131 \\
5 & 4823 & 3989 & 834 & 4 & 209 \\
6 & 3481 & 2890 & 591 & 4 & 148 \\
& Rata-rata & & & & 163 \\
\hline
\end{tabular}

Adapun hasil pengujian delay yang dilakukan pada Fakultas Sains dan Teknologi UIN Sunan Kalijaga Yogyakarta, data hasil pengujian Throughput, Packet Loss, Delay Lt.4 dapat dilihat pada tabel 10,11, dan 12:

Tabel 10. Throughput SUKAnet WiFi Lt.4

\begin{tabular}{cccc}
\hline \multirow{2}{*}{$\begin{array}{c}\text { Hari } \\
\text { Ke }\end{array}$} & $\begin{array}{c}\text { Total paket } \\
\text { (Mbytes) }\end{array}$ & Perhitungan Throughput \\
\hline 1 & 4885 & 60 & $\begin{array}{c}\text { Throughput } \\
\text { (MBps) }\end{array}$ \\
2 & 4097 & 60 & 8.1 \\
3 & 5239 & 60 & 6.8 \\
4 & 3928 & 60 & 8.7 \\
5 & 3140 & 60 & 6.5 \\
6 & 3193 & 60 & 5.2 \\
& Rata-rata & & 5.3 \\
\hline
\end{tabular}

Tabel 11. Packet Loss SUKAnet WiFi Lt.4

\begin{tabular}{cccc}
\hline \multirow{3}{*}{$\begin{array}{c}\text { Hari } \\
\text { Ke }\end{array}$} & $\begin{array}{c}\text { Jumlah paket } \\
\text { diterima (paket) }\end{array}$ & $\begin{array}{c}\text { Jumlah paket dikirim } \\
\text { (paket) }\end{array}$ & $\begin{array}{c}\text { Pengukuran packet loss } \\
\text { ratio }(\%)\end{array}$ \\
\hline 1 & 25 & 60 & 58 \\
2 & 11 & 60 & 82 \\
3 & 34 & 60 & 43 \\
4 & 49 & 60 & 18 \\
5 & 37 & 60 & 38 \\
6 & 19 & 60 & 68 \\
& Rata-rata & & 51 \\
\hline
\end{tabular}


Tabel 12. Delay SUKAnet WiFi Lt.4

\begin{tabular}{cccccc}
\hline \multirow{5}{*}{$\begin{array}{c}\text { Hari } \\
\text { Ke }\end{array}$} & $\begin{array}{c}\text { Waktu paket } \\
\text { diterima } \\
\text { (millisecond) }\end{array}$ & $\begin{array}{c}\text { Waktu paket } \\
\text { dikirim } \\
\text { (millisecond) }\end{array}$ & $\begin{array}{c}\text { Selisih waktu } \\
\text { (millisecond) }\end{array}$ & Paket data & $\begin{array}{c}\text { Delay } \\
\text { (millisecond) }\end{array}$ \\
\hline 1 & 4832 & 3934 & 898 & 4 & 225 \\
2 & 3887 & 2983 & 904 & 4 & 226 \\
3 & 4490 & 3934 & 556 & 4 & 139 \\
4 & 3850 & 2978 & 872 & 4 & 218 \\
5 & 4398 & 3987 & 411 & 4 & 103 \\
6 & 4844 & 3980 & 864 & 4 & 216 \\
& Rata-rata & & & & 188 \\
\hline
\end{tabular}

Di bawah ini gambar dari grafik pengujian Throughput

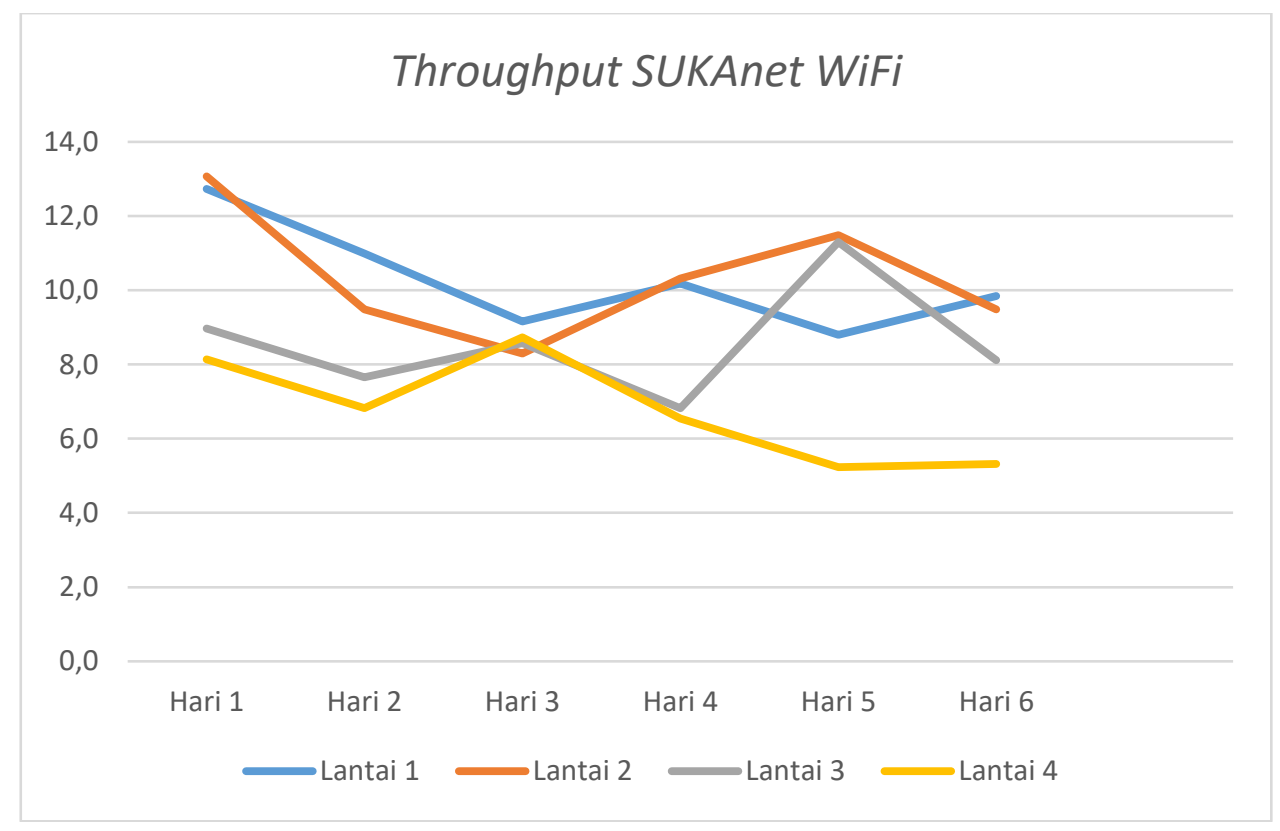

Gambar 3. Pengujian Throughput 
Di bawah ini gambar dari grafik pengujian Packet Loss

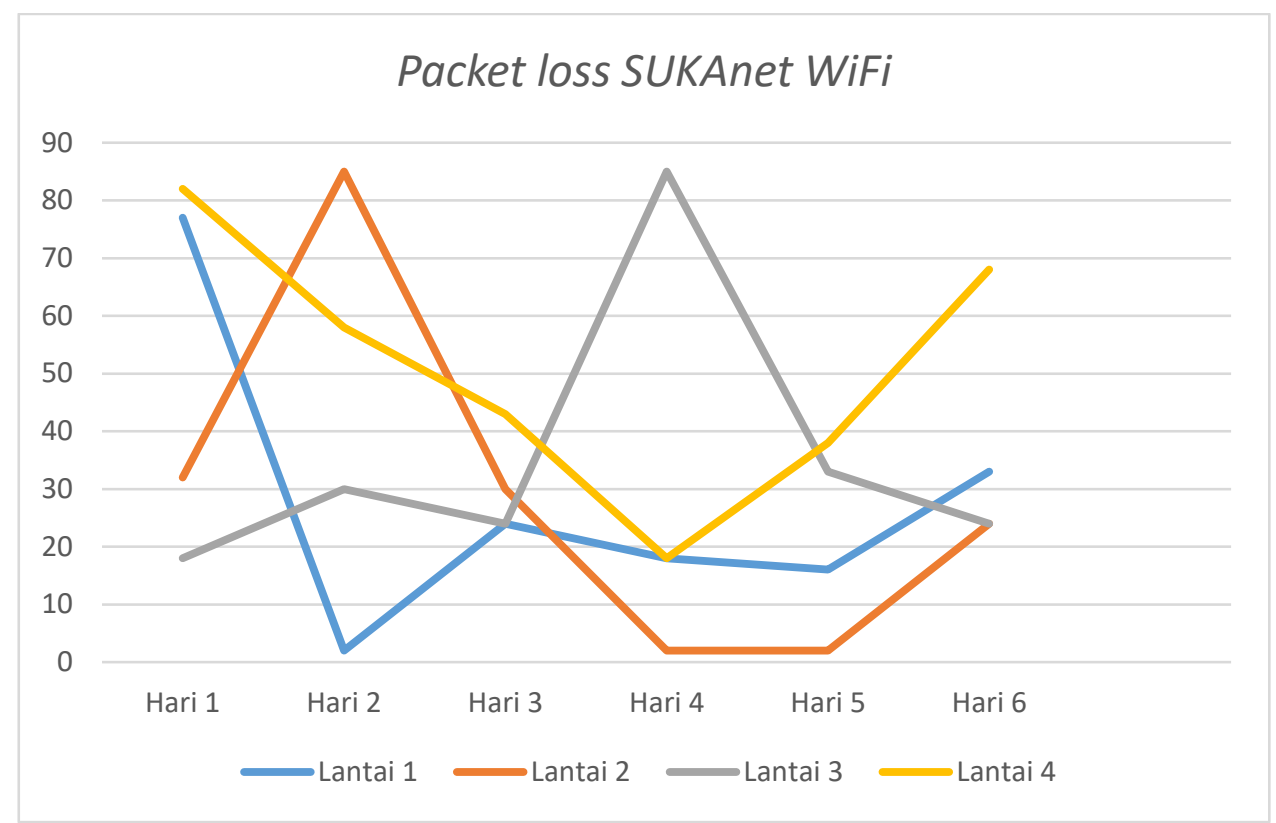

Gambar 4. Pengujian packet loss

Di bawah ini gambar dari grafik pengujian Delay

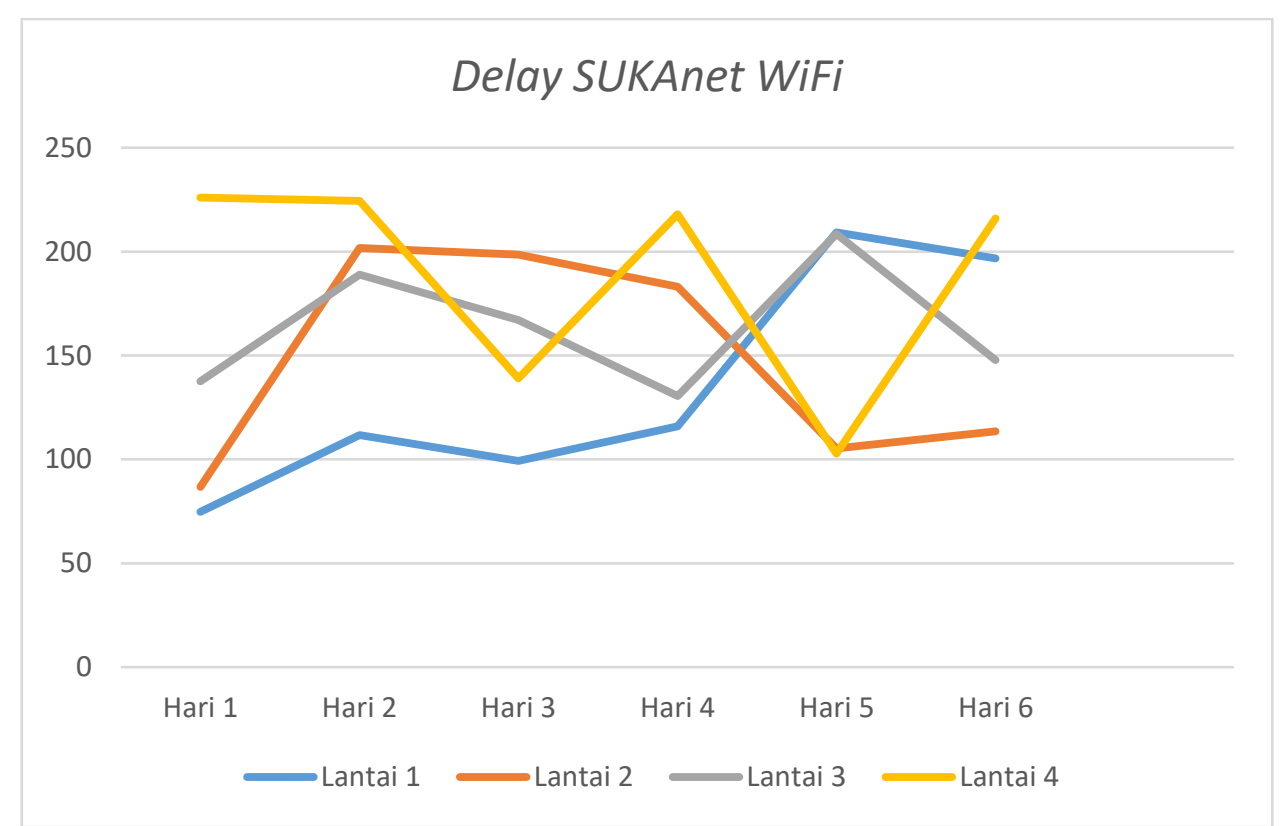

Gambar 5. Pengujian delay

\subsection{Pembahasan Throughput}

Pengukuran yang dilakukan selama kurun waktu 6 hari dengan SUKAnet WiFi didapatkan Throughput sebesar 9.0 MBps.
Menurut penelitian tesis dari [5] dari hasil Throughput tersebut kemudian dibagi dengan kecepatan akses internet yang diuji menggunakan aplikasi speedtest yaitu 17,7 
MBps untuk mencari persentase dari Throughput. Hasil dari persentase Throughput didapat nilai sebesar $50 \%$. Dari hasil pengujian tersebut dapat disimpulkan bahwa menurut standarisasi TIPHON [6] Throughput SUKAnet WiFi masuk dalam kategori Sedang. Maka jaringan SUKANet WiFi masih belum maksimal untuk melayani kebutuhan akses internet pada trafik pengguna yang tinggi.

\subsection{Pembahasan Delay}

Pengukuran yang dilakukan selama kurun waktu 6 hari dengan SUKAnet WiFi didapatkan delay sebesar 159 milidetik dalam standarisasi TIPHON masuk dalam kategori Bagus dan dapat diterima dengan ketentuan bahwa administrator mengetahui waktu transmisi dan dampaknya pada kualitas transmisi pengguna aplikasi.

\subsection{Pembahasan Packet Loss}

Pengukuran Packet Loss dengan menggunakan jaringan SUKAnet WiFi didapatkan nilai Packet Loss sebesar $36 \%$ dalam standarisasi TIPHON masuk pada kategori jelek. Menurut hasil yang didapatkan kualitas layanan yang diberikan SUKAnet WiFi masih jauh dari standarisasi yang diberikan dan perlu dilakukan peningkatan.

\section{PENUTUP}

Berdasarkan hasil pengukuran dan pengujian dalam penelitian yang telah dilakukan, performa layanan internet pada SUKAnet WiFi di Fakultas Sains dan Teknologi UIN Sunan Kalijaga memiliki tingkat kualitas Throughput $50 \%$ jika dikategorikan menurut standarisasi TIPHON adalah Sedang. Dalam hal ini perlu dilakukan perbaikan layanan supaya dapat memenuhi kebutuhan layanan internet dengan maksimal pada trafik pengguna yang tinggi. Besar delay sebesar 159 milidetik jika dikategorikan menurut standarisasi TIPHON adalah bagus, dalam hal ini dapat diterima dengan ketentuan bahwa administrator mengetahui waktu transmisi dan dampaknya pada kualitas transmisi pengguna aplikasi. Tetapi memiliki nilai Packet Loss sebesar $36 \%$ jika dikategorikan menurut standarisasi TIPHON adalah jelek. Hal ini disebabkan karena banyak user yang mengakses layanan internet pada jam sibuk.
Faktor yang mempengaruhi adalah terjadinya tabrakan/tumbukan antara data pada jaringan yang dapat berpengaruh pada semua aplikasi yang ada pada jaringan internet, meskipun jumlah bandwidth cukup tersedia untuk aplikasi tersebut. Pada umumnya peringkat jaringan memiliki buffer untuk menampung data yang diterima atau pembuangan paket di terminal sampai menunggu paket terakhir datang.

\section{KESIMPULAN}

Berdasarkan hasil pengukuran, pengujian dalam penelitian yang telah dilakukan, performa layanan internet pada SUKAnet WiFi di fakultas Sains dan Teknologi UIN Sunan Kalijaga didapatkan kesimpulan bahwa performa kualitas layanan jaringan SUKAnet WiFi memiliki tingkat kualitas Throughput 50 $\%$ jika dikategorikan menurut standarisasi TIPHON adalah sedang. Maka perlu dilakukan perbaikan layanan supaya dapat memenuhi kebutuhan layanan internet dengan maksimal pada trafik pengguna yang tinggi.

Besar delay sebesar 159 milidetik jika dikategorikan menurut standarisasi TIPHON adalah bagus, dalam hal ini dapat diterima dengan ketentuan bahwa administrator mengetahui waktu transmisi dan dampaknya pada kualitas transmisi pengguna aplikasi. Tetapi memiliki nilai Packet Loss sebesar $36 \%$ jika dikategorikan menurut standarisasi TIPHON adalah jelek.

Kualitas jaringan SUKAnet WiFi masih jauh jika dilihat dari standar kualitas layanan dari TIPHON dan administrator jaringan SUKAnet WiFi perlu melakukan tidak lanjut agar dapat memberikan pelayanan yang optimal kepada user SUKAnet WiFi.

\section{DAFTAR PUSTAKA}

[1] Andi, Madcoms. 2011 "Membangun Sistem Jaringan Wireless: Untuk Pemula" Yogyakarta: Andi.

[2] Syafrizal, M. 2005. Pengantar Jaringan Komputer. Yogyakarta: Andi Offset.

[3] Ningsih, YK, dkk. 2004. Analisis Quality Of Service (QoS) pada Simulasi Jaringan Multiprotocol abel Switching Virtual Private Network (Mpls Vpn), JETri, vol.3, no.2, pp.33-48, [Available] online:

[4] Fatoni. 2011, "Analisis Kualitas Layanan Jaringan Intranet (Studi Kasus 
Universitas Bina Darma)" Jurnal Universitas Bina Darma, Palembang.

[5] Diponegoro, M. 2015 "Analisis Quality Of Service (Qos) Pada Jaringan Internet Dengan Metode Fixed Daily Measurement Interval (Fdmi) Dan Non Fdmi Studi Kasus: Ugm-Hotspot Pascasarjana Ilmu Komputer Universitas Gadjah Mada" Tesis Ilmu Komputer UGM.

[6] TIPHON. 1999. Telecommunications and Internet Protocol Harmonization Over Network (TIPHON) General aspect of Qoality of Service (Qos). DTR/TIPHON-05006 (cb001cs.pdf). 